\title{
Determination of Glucocorticoids using Cosurfactants Ultrasonic-Thermostatic-Assisted Cloud Point Extraction Followed by High Performance Liquid Chromatography
}

\author{
Hui Qin, ${ }^{a}$ Gao Feng Li, $^{b}$ Nan Chen ${ }^{b}$ and Ya Ling Yang*,a \\ ${ }^{a}$ Faculty of Life Science and Technology, Kunming University of Science and Technology, 650500 Kunming, P. R. China \\ ${ }^{b}$ Tumor Hospital of Yunnan Province, 650106 Kunming, P. R. China
}

\begin{abstract}
Foi desenvolvida uma nova abordagem de extração no ponto nuvem assistida por cossurfactantes ultrassônicos-termostáticos (CUS-CPE), combinada à cromatografia líquida de alta eficiência e deteç̧ão por ultavioleta (CLAE-UV), para a análise de glicocorticoides (dipropionato de beclometasona (BD), butirato de hidrocortisona (HB) e fenilpropionato de nandrolona (NPP)) em amostras de urina humana. Neste estudo, quatro sistemas de extração diferentes no ponto nuvem (CPE) são discutidos, incluindo ácido nonanoico DC-193, sulfato de sódio DC-193, ácido láurico DC-193 e o clássico sulfato de Triton X-100. Entre eles, sulfato de sódio DC-193 e Triton X-100 têm sido estudados nos últimos anos. Comparando com os dois primeiros sistemas, o ácido nonanoico DC-193 teve um ponto nuvem (CP) mais baixo, pouca absorbância UV e provocou danos menores à coluna de três glicocorticoides na mesma concentração de agente tensoativo, necessária como processo de pré-concentração, prévio à CLAE. Diagramas de fase foram usados para estudar os comportamentos de cavitação e transferência de massa das duas fases em micelas de agente tensoativo de silicone orgânico do tipo poliéter, dimeticona PEG-12 (DC-193). Os volumes da fase rica em agentes tensoativos obtidos foram muito pequenos (o fator de enriquecimento (EF) foi 35), o qual é muito menor e apresenta uma fase de separação mais rápida do que para Triton X-100 na mesma concentração de agente tensoativo. A linearidade foi investigada entre $1 \mathrm{e} 350 \mathrm{ng} \mathrm{mL}^{-1}$. Os limites de detecção (LOD) estimados foram 1,29 para BD, 2,67 para HB e $3,33 \mathrm{ng} \mathrm{mL}^{-1}$ para NPP, respectivamente. O sistema proposto é rápido e eficiente, com recuperação dos três glicocorticoides superior a $85 \%$, o que é similar ou melhor do que os dados relatados na literatura. O método mostrou-se seletivo, linear, preciso e reprodutível, tendo sido aplicado com sucesso na análise de glicocorticoides em amostras de urina humana.
\end{abstract}

A novel approach, cosurfactants ultrasonic-thermostatic-assisted cloud point extraction (CUS-CPE) combined with high performance liquid chromatography and ultraviolet detection (HPLC-UV) is developed for the analysis of glucocorticoids (beclometasone dipropionate (BD), hydrocortisone butyrate (HB) and nandrolone phenylpropionate (NPP)) in human urine samples. In this study, four different cloud point extraction (CPE) systems are discussed, including DC-193-nonanoic acid, DC-193-sodium sulfate, DC-193-lauric acid and the classic Triton X-100 sulfate systems. Among them, DC-193-sodium sulfate and the classic Triton X-100 sulfate systems has been studied in the past few years. Comparing with the first two systems, DC-193-nonanoic acid system had a lower cloud point (CP), little UV absorbance and it is less damaging to the column of three glucocorticoids in same surfactant concentration which was required for application as a pre-concentration process prior to HPLC. Phase diagrams were used to study the cavitation and mass transfer behaviors of the two phases on micelles of polyether type organic silicon surfactant, PEG-12 dimethicone (DC-193). The volumes of surfactant-rich phase obtained were very small (the enrichment factor (EF) was 35), which was much smaller and had a quick phase separating speed than that of Triton X-100 in the same surfactant concentration. Linearity was investigated from 1 to $350 \mathrm{ng} \mathrm{mL}^{-1}$. The limits of detection (LOD) thus estimated were 1.29 for $\mathrm{BD}, 2.67$ for $\mathrm{HB}$ and $3.33 \mathrm{ng} \mathrm{mL}^{-1}$ for NPP, respectively. In proposed CPE step is rapid and effective to obtain recovery of three glucocorticoids higher than $85 \%$, which is similar or better than literature reported data. The method was shown to be selective, linear, precise and reproducible and successfully applied for the analysis of glucocorticoids in human urine samples.

Keywords: CUS-CPE, glucocorticoids, DC-193, human urine, HPLC-UV

\footnotetext{
*e-mail: yilyil8@163.com
} 


\section{Introduction}

Glucocorticoids have a long history of use in human and veterinary medicine. ${ }^{1}$ Beclometasone dipropionate (BD), hydrocortisone butyrate (HB) are epimeric synthetic glucocorticoids, and are employed frequently as antiinflammatory and antiallergic drugs. They are effective in a variety of diseases including ketosis, allergic reactions, pregnancy toxemia, shock and mastitis. ${ }^{2,3}$ However, the mechanisms regulating these effects are not fully understood. The determination of glucocorticoids in different human fluids, such as urine, is of great interest in medical diagnostics, especially for patients suffering from Parkinson's disease or phaeochromocytoma and stress. An early and accurate determination of the glucocorticoids concentration in urine could prevent unnecessary drug treatment. ${ }^{4}$

Therefore, accomplishment of sensitive, rapid and simple analytical methods of the glucocorticoids in human urine are paramount. Several HPLC (high performance liquid chromatography), LC-MS (liquid chromatography coupled to mass spectrometry) and electrochemical methods have been reported in the literature describing the analysis of glucocorticoids..$^{5-13}$ Urine samples are usually enriched by optical fiber biosensor or solid-phase extraction by HPLC-MS/MS (high performance liquid chromatography-tandem mass spectrometry) method or voltammetric techniques..$^{14,15}$

This work aimed at the development of cosurfactants ultrasonic-thermostatic-assisted cloud point extraction (CUS-CPE) for analysis of three glucocorticoids based on high performance liquid chromatography and ultraviolet detection (HPLC-UV). Non-ionic surfactant DC-193 was first used to extract and preconcentrate glucocorticoids in human urine. In the new process, glucocorticoids and DC-193 formed homogeneous solution, which was solubilized with nonionic surfactants micelle solution, then concentrated along with micelles into a surfactantrich phase by phase separation after ultrasonic-thermostat over cloud point. ${ }^{16,17}$ However, the well-known nonionic surfactants, such as Triton $\mathrm{X}$ and PONPE series, had a high background absorbance in the ultraviolet or their fluorescence signals interfere in the fluorescent region, due to the presence of an aromatic moiety in their structure. ${ }^{18}$ Therefore, using a surfactant without UV absorbance or fluorescence signals was considered to be the best way to avoid the chromatographic overlapping. The DC-193nonanoic acid system had little UV absorbance, so could be injected into the HPLC with UV detector directly without any pretreatment. Comparing with Triton X-100 sulfate system, it had higher EF and recovery in the same surfactant concentrations and high phase separating speed at the same time. The amount of nonanoic acid played a very important role in the phase separation and extraction. The results obtained by the CUS-CPE method were compared with four different systems (DC-193-nonanoic acid, DC-193-sodium sulfate, DC-193-lauric acid and the classic Triton X-100 sulfate systems) encompassing aspects such as equilibration temperature, incubation time, recovery, phase diagrams, enrichment factor and so on, and this study had been rarely reported in the literature.

\section{Experimental}

\section{Materials and reagents}

All reagents used were HPLC grade, and purified water from a Milli Q system (Millipore, Mil-ford, MA, USA) was used throughout the experiments. BD, HB and NPP were obtained from Sigma (St. Louis, Mo., USA). Standard stock solutions of BD, HB and NPP (nandrolone phenylpropionate) were prepared in methanol at a concentration of $1 \mathrm{mg} \mathrm{mL}-1$. The structures of the three glucocorticoids and some characteristics are shown in Table 1. Methanol (HPLC grade) was obtained from Merck (Darmstadt, Germany). The non-ionic surfactant DC-193 (Acros Organics, New Jersey, USA) was used without further purification, to prepare $10 \%(\mathrm{v} / \mathrm{v})$ aqueous solutions. Nonanoic acid was obtained from Sigma (St. Louis, Mo., USA).

\section{Apparatus}

Chromatographic separation and evaluation were performed on an HPLC system consisting of a vacuum degasser, an auto sampler, a quaternary pump, and a diode array detector (Agilent 1200 Series, Agilent Technologies (California, USA)). A thermostatic SHY-2A water bath (Tianjin, China) was used to study temperature effects on CPE. An ultrasonic bath from Kunshan ultra-sonic instrument plant (Jiangsu, China) was used for extraction of samples. A 80-2 centrifuge (Shanghai, China) was used for complete phase separation.

\section{Chromatographic conditions}

The HPLC-UV system was used in the present study. Separation was carried out on a reversed phase Agilent TC-C18 analytical column $(150 \mathrm{~mm} \times 4.6 \mathrm{~mm}$, i.d, $5 \mu \mathrm{m})$. $100 \%$ acetonitrile and $0.1 \%$ formic acid were used as mobile phase with the gradient program as follows: $80 \%$ acetonitrile ( 0 to $6 \mathrm{~min}$ ), ramped to $90 \%$ acetonitrile ( 6.5 to 
Table 1. Characteristics of the studied glucocorticoids

Name Abbreviation

$8 \mathrm{~min})$. The flow rate was maintained at $0.8 \mathrm{~mL} \mathrm{~min}$. The injection volume was $10 \mu \mathrm{L}$. The system was allowed to stabilize for 1 to 2 min under the initial conditions. The prepared mobile phase was filtered and degassed using ultrasonic agitation. The column temperature was maintained at $35^{\circ} \mathrm{C}$ and the wavelength of the UV Detector was at a fixed wavelength of $240 \mathrm{~nm}$.

\section{Cloud point procedure}

\section{Extraction from aqueous samples}

A $2 \mathrm{~mL}$ aliquot of the solution containing different concentrations of glucocorticoids (BD, HB and NPP) was placed in centrifuge vials. Then $2.5 \mathrm{~mL}$ of $10 \%$ $(\mathrm{v} / \mathrm{v})$ of DC-193 stock solution and $1 \mathrm{~mL}$ of $100 \%(\mathrm{v} / \mathrm{v})$ of nonanoic acid were added, and the mixtures were diluted with doubly distilled water to $10 \mathrm{~mL}$. The mixture solution was left standing for $5 \mathrm{~min}$, and incubated into an ultrasonic water bath performed at $35 \mathrm{kHz}$ of ultrasound frequency and $65{ }^{\circ} \mathrm{C}$ for $30 \mathrm{~min}$. Then the phase were separated by centrifugation for $3 \mathrm{~min}$ at $4000 \mathrm{rpm}$. The lower water phase was carefully removed by using a syringe with a long needle that passed through the upper surfactant-rich phase. The surfactant-rich phase was left in the tube and diluted to $0.5 \mathrm{~mL}$ with acetonitrile. Therefore, EF of about 35 was finally obtained, and 10 $\mu \mathrm{L}$ of the surfactant-rich phase solution were injected into the HPLC system. A diagramatic sketch of CUS-CPE is shown in Figure 1.

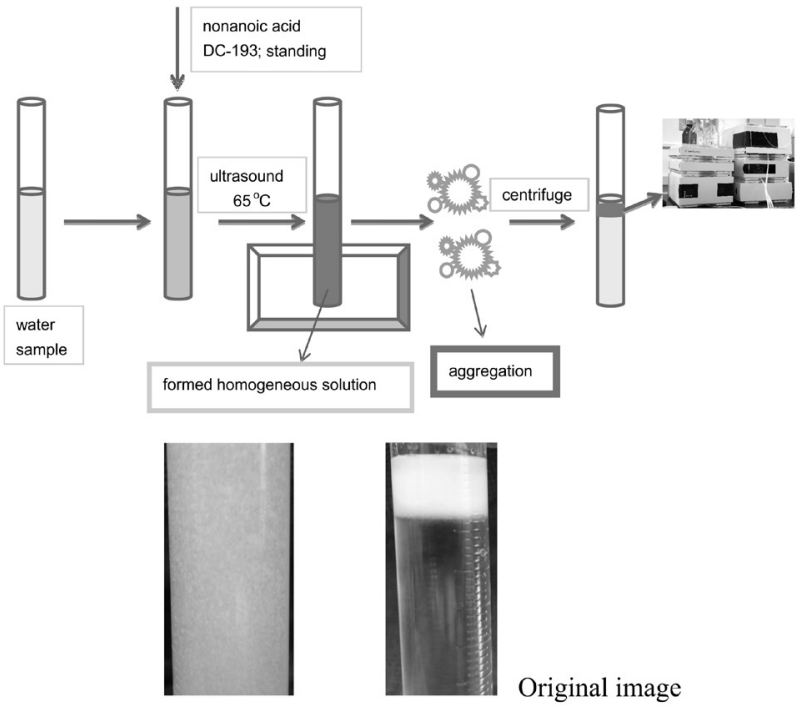

Figure 1. Schematic representation of the CUS-CPE enrichment method (nonanoic acid were used as cosurfactants, providing the hydrophobic pre-organization in CUS-CPE).

\section{Sampling and pretreatment}

Urine samples were obtained from healthy volunteers in a certified laboratory of clinical analysis. Urine samples were stored at $-18{ }^{\circ} \mathrm{C}$ until further processing for each of the analytical methodologies implemented in this work. An amount of $5 \mathrm{~mL}$ of urine were added to a $50 \mathrm{~mL}$ flask and diluted to volume with purified water. Each prepared sample was adjusted to a $\mathrm{pH}$ value of approximately 6.5 with $0.5 \mathrm{~mol} \mathrm{~L}^{-1}$ of $\mathrm{NaOH}$. The solution was transferred to 
a test tube, and was centrifuged at $4000 \mathrm{rpm}$ for $30 \mathrm{~min}$. Then the supernatant fluid was diluted with purified water to a final volume of $10 \mathrm{~mL}$. The surfactant-rich phase was separated as described previously in the "Extraction from aqueous samples" section.

\section{Results and Discussion}

\section{Optimization of the CPE conditions}

The cloud point temperature of DC-193 is 95 or 96 ${ }^{\circ} \mathrm{C}$, but the cloud point can be reduced to $65^{\circ} \mathrm{C}$ through a series of optimization of conditions. Therefore, DC-193 is a better non-ionic surfactant in the cloud point extraction.

\section{Comparison of data of four studied systems}

Some additive molecules (cosurfactants) were adsorbed on the surface of micelles to inhibit the micellization resulting in the increase of $\mathrm{CP}$, while the molecules of the latter could be solubilized in the layer of micelles to lead the micelles to swell, resulting in the decrease of CP..$^{16,19,20}$ In this work, four studied systems are used to assess this behavior and the organic acids are considered as cosurfactants. The results reveal that the nonanoic acid has a better effect than lauric acid at the same concentration. (see Figure 2).

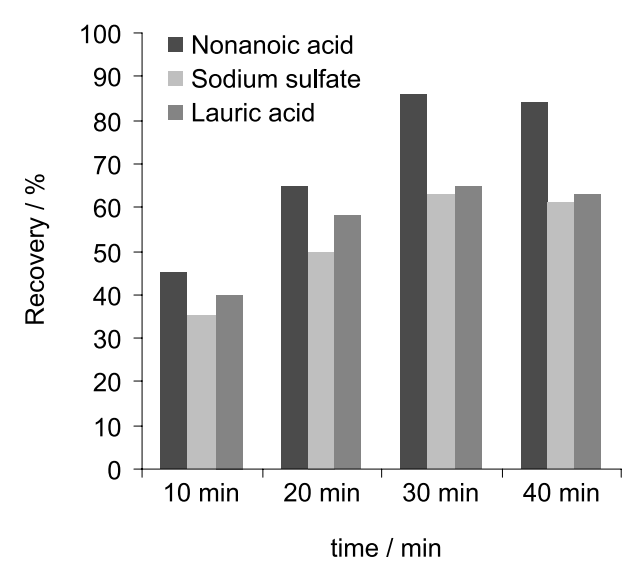

Figure 2. Comparison of data of four studied systems.

The $\mathrm{CP}$ that could be reduced from $96{ }^{\circ} \mathrm{C}$ to $65^{\circ} \mathrm{C}$ was significantly affected by the amount of organic acids. Lauric acid and nonanoic acid are saturated straight chain monoacids. When the amount of $-\mathrm{OH}$ was sufficient, most molecules which were soluble in micellar palisade layer existed around the non-ionic surfactant polar groups. The hydration degree of the surfactants was reduced due to the steric effect, which led to a lower CP. When a large number of $-\mathrm{OH}$ was present, part of it wasadsorbed on the micellar palisade layer and interface..$^{20}$ The appropriate concentration was at $10 \%$, which was adopted as the optimum amount to achieve best analytical signals and extraction efficiency. By comparison of two systems, DC-193 nonanoic acid system was selected in the process (see Figure 3).

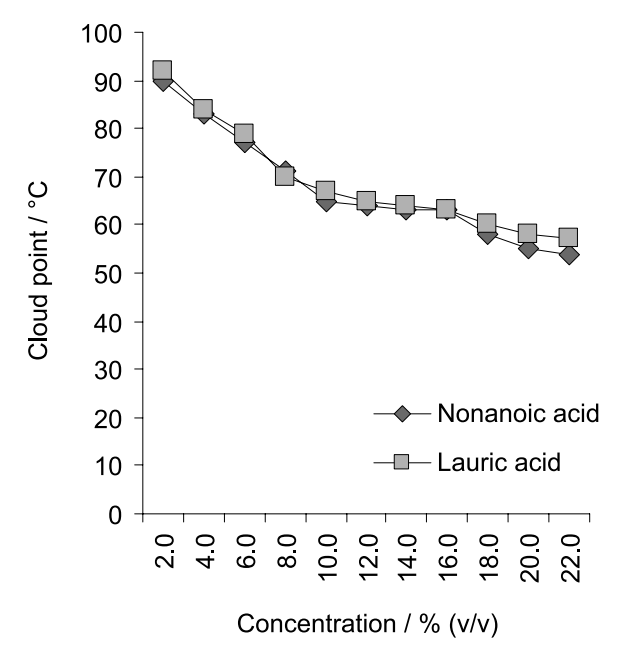

Figure 3. Effect of organic acid concentration on the CP. Other extraction conditions-CUS-CPE equilibrium time: $30 \mathrm{~min}$; concentration of DC-193: $2.5 \%(\mathrm{v} / \mathrm{v})$; equilibrium temperature: $65^{\circ} \mathrm{C}$; ultrasonic joined.

Each sample was assayed six times under identical experimental conditions to confirm the reproducibility of analytical data. Figure 4 shows typical HPLC chromatograms of extracted and pre-concentrated glucocorticoids in the four studied systems. It was found that the DC-193 nonanoic acid system is superior to the other three studied systems (DC-193-sodium sulfate, DC-193-lauric acid and the classic Triton X-100 sulfate systems) in recovery, EF and assay sensitivity. The comparison of another three studied systems is shown in Figure 4 and Table 2.

\section{Characteristic performance data}

\section{Effect of the concentration of surfactants}

The theoretical pre-concentration factor depends on the concentration of surfactant. Aqueous solutions containing a mixture of standard glucocorticoids $\left(50 \mathrm{ng} \mathrm{mL}^{-1}\right.$ each) were extracted by CUS-CPE with different concentrations of DC-193 in the range of $0.5-6 \%(\mathrm{v} / \mathrm{v})$. The effect of the concentration of surfactant was examined and the results are presented in Figure 5.

The highest recovery is at $2.5 \%$ concentration of DC-193 solution. Based on these experimental results, $2.5 \%$ of DC-193 was adopted as the optimum amount to achieve best analytical signals and extraction efficiency. The other parameters, including acid, equilibration temperature and time, were optimized in subsequent experiments. 

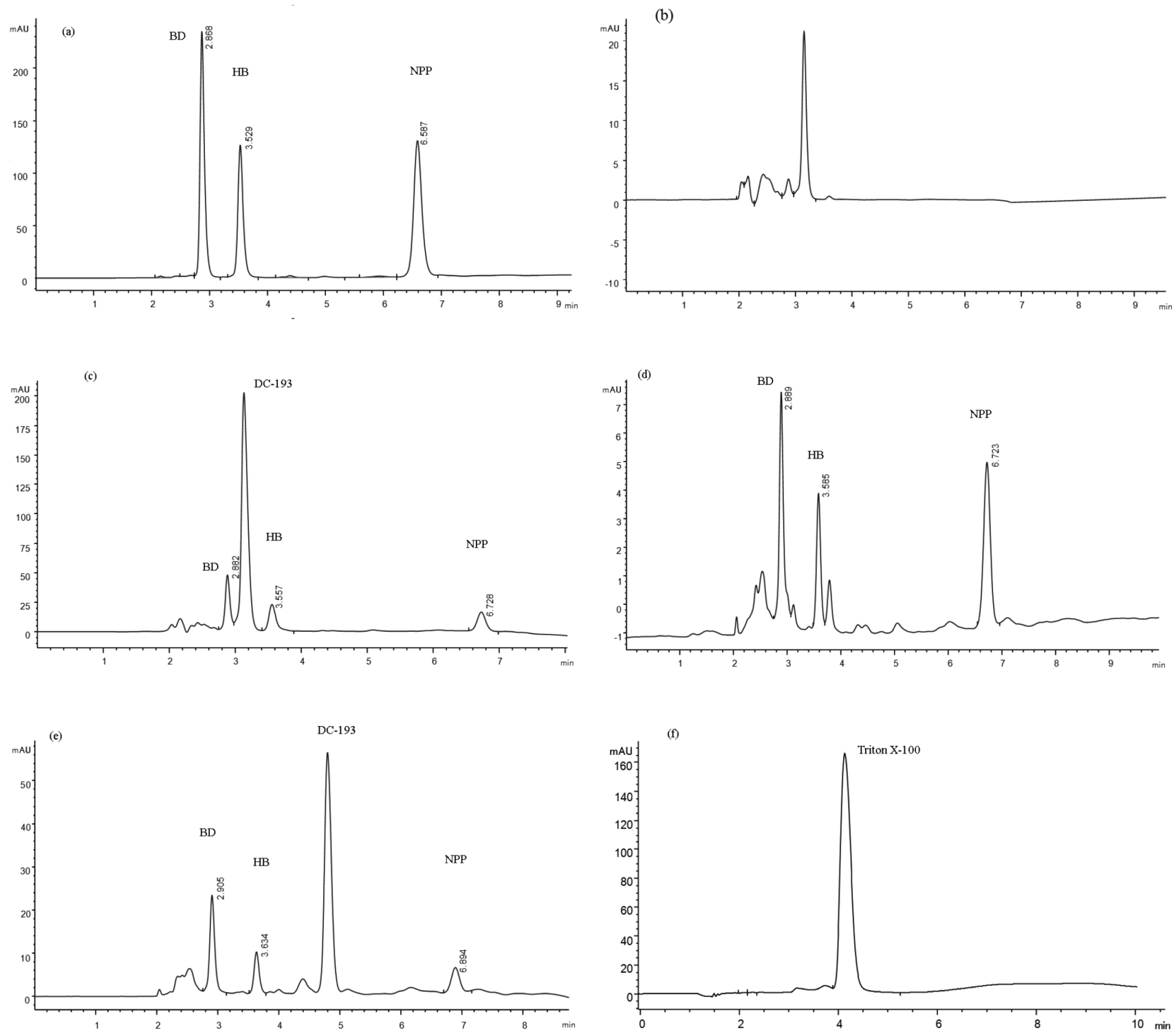

Figure 4. HPLC-UV chromatograms: (a) standard $\left(50 \mathrm{ug} \mathrm{mL}^{-1}\right)$, (b) black urine, (c) urine spiked with BD, HB and NPP $\left(50 \mathrm{ng} \mathrm{mL}^{-1}\right)$ in DC-193 nonanoic acid system, (d) urine spiked with BD, HB and NPP $\left(50 \mathrm{ng} \mathrm{mL}^{-1}\right)$ in DC-193 sodium sulfate system, (e) urine spiked with BD, HB and NPP $\left(50 \mathrm{ng} \mathrm{mL}^{-1}\right)$ in DC-193 lauric acid system and (f) urine spiked with BD, HB and NPP (50 ng mL $\left.{ }^{-1}\right)$ in Triton X-100 sulfate system. Peak nr: (1) BD; (2) HB; (3) NPP; (4) DC-193.

Table 2. Comparison of data of four studied systems

\begin{tabular}{lccc}
\hline Systems & Recovery / \% & EF & LOD / $\left(\mathrm{ng} \mathrm{mL}^{-1}\right)$ \\
\hline DC-193 nonanoic acid & 86 & 35 & 1.29 \\
DC-193 sodium sulfate & 63 & 25 & 20.79 \\
DC-193 lauric acid & 65 & 30 & 11.42 \\
Triton X-100 sulfate & 52 & 35 & 18.94 \\
\hline
\end{tabular}

\section{Effect of temperature and equilibrium time}

It was found that the effects of various temperatures on the extraction recovery was a key for $\mathrm{CPE}$. If the temperature was lower than the $\mathrm{CP}$, two phases could not be formed. ${ }^{21}$ Briefly, the tubes were kept at different temperatures ranging from $55^{\circ} \mathrm{C}$ to $85^{\circ} \mathrm{C}$ for 30 min maintained in a water bath. It was found that two phases could be formed quickly for $30 \mathrm{~min}$ when the temperature was greater than or equal to $65{ }^{\circ} \mathrm{C}$. At the same time, recovery was examined under different temperatures. The results showed that the recovery increases from 55 to $65^{\circ} \mathrm{C}$ and decreases quickly thereafter (Figure 6). However, part of the analytes may be volatilized if the temperature is too high.

For further experiments, $65{ }^{\circ} \mathrm{C}$ was therefore used as the temperature for extraction. The effect of heating time was also studied to determine the maximum recovery. It was observed that beyond $30 \mathrm{~min}$ there was a decrease on recovery for the entire temperature range studied. 


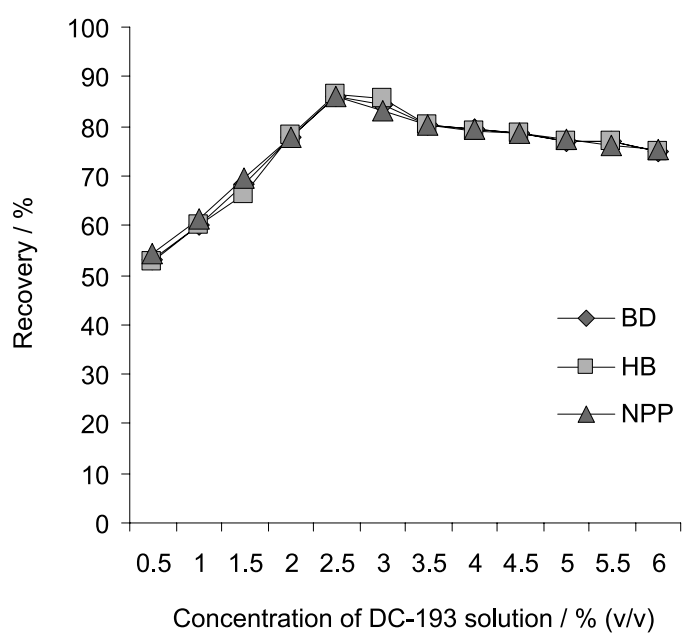

Figure 5. Effect of DC-193 concentration on the recovery. Other extraction conditions-CUS-CPE equilibrium temperature: $65^{\circ} \mathrm{C}$; equilibrium time: $30 \mathrm{~min}$; nonanoic acid $1 \mathrm{~mL}$; ultrasonic joined.

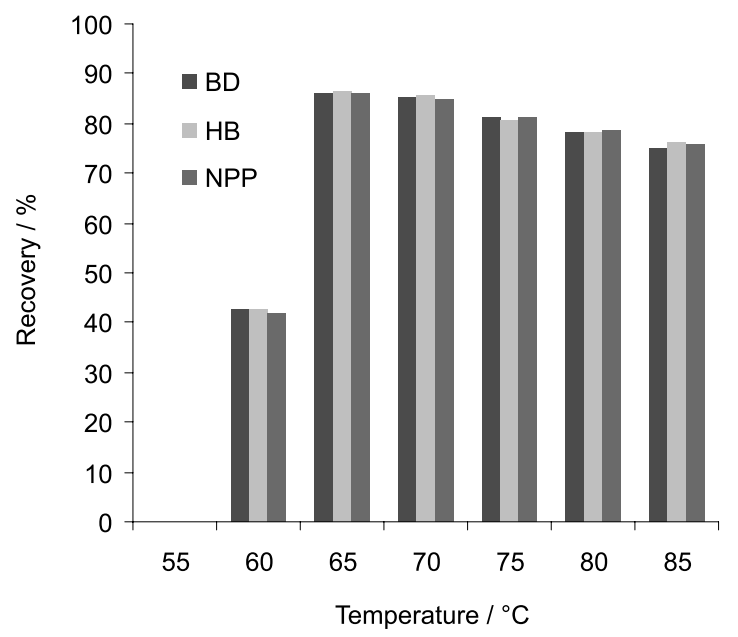

Figure 6. Effect of equilibrium temperature on the recovery. Other extraction conditions-CUS-CPE equilibrium time: $30 \mathrm{~min}$; concentration of DC-193: 2.5\% (v/v); nonanoic acid $1 \mathrm{~mL}$; ultrasonic joined.

It was therefore decided to carry out the extraction of glucocorticoids at $65{ }^{\circ} \mathrm{C}$ for $30 \mathrm{~min}$ as these conditions provided the maximum recovery (Figure 7 ).

\section{Effect of the amount of organic acid added}

The CP was significantly affected by the amount of organic acids. ${ }^{19}$ The $\mathrm{CP}$ continued to decline, but it had little change after $65{ }^{\circ} \mathrm{C}$. The appropriate concentration was at $10 \%$, which was adopted as the optimum amount to achieve best analytical signals and recovery. An amount of $10 \%(\mathrm{v} / \mathrm{v})$ of nonanoic acid was chosen in the process (see Figures 2, 3, 6).

\section{CPE phase diagrams}

Phase behavior of an aqueous nonionic surfactant micelle solution is very sensitive to temperature. ${ }^{22,23}$ Above

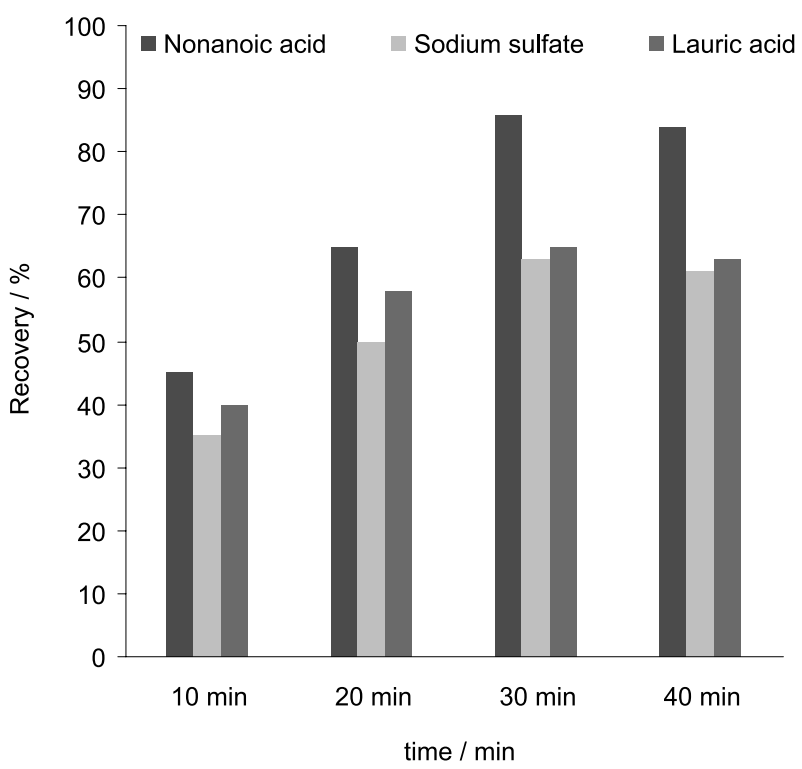

Figure 7. Effect of equilibrium time on the recovery. Other extraction conditions-CUS-CPE equilibrium temperature: $65^{\circ} \mathrm{C}$; concentration of DC-193: 2.5\% (v/v); nonanoic acid 1mL; ultrasonic joined.

a certain temperature, a single phase nonionic surfactant micelle aqueous solution separates into a dilute phase and a surfactant-rich phase or coacervate phase.

The surfactant-rich phase volume percentage $\left(\mathrm{Vs} / \mathrm{Vs}+\mathrm{Vw}_{\mathrm{w}}\right)$ of glucocorticoids were used to evaluate the CUS-CPE performance, where Vs was the volume of the surfactant-rich phase and $\mathrm{Vw}$ was the volume of the water phase. Figure 8 shows the phase separation process under the heating condition in different time of two surfactant solutions about four studied systems. The volume of the surfactant-rich phase was increased gradually with the extension of heating time to achieve the ultimate stable state. The interaction between solute and surfactant was treated as the difference of density and the influence of thermal motion in the interior or outer palisade layers of the micelles. In most cases, after 30-40 min the volume of the surfactant-rich phase could achieve stable state. Figure 8(a-d) showed that different time of surfactant solutions, activities and ultrasonic joined influenced the phase separation process. As could be seen from Figure 8a, compared with the curves $b-d$, the phase equilibrium time was reduced to 30 min by adding nonanoic acid and ultrasonic bath. Phase separation process of DC-193 micelles could be accelerated with CUS-CPE effectively at $65^{\circ} \mathrm{C}$ for $30 \mathrm{~min}$, which could be got in the clear separation interface. It is found that $\mathrm{CP}$ was been reduced significantly after adding nonanoic acid compared with the original $\mathrm{CP}$. EF of about 35 was finally obtained. The EF could be expressed as: $\mathrm{EF}=\left(\mathrm{M}_{0} / \mathrm{V}_{0}\right) /\left(\mathrm{M}_{1} / \mathrm{V}_{1}\right)$, where $\mathrm{EF}$ was enrichment factor, $\mathrm{M}_{0}$ was the amount of glucocorticoids added before enrichment, $\mathrm{V}_{0}$ was the volume of solution before enrichment and 
$\mathrm{M}_{1}$ and $\mathrm{V}_{1}$ represented the amount of glucocorticoids added and the volume of solution after enrichment, respectively.

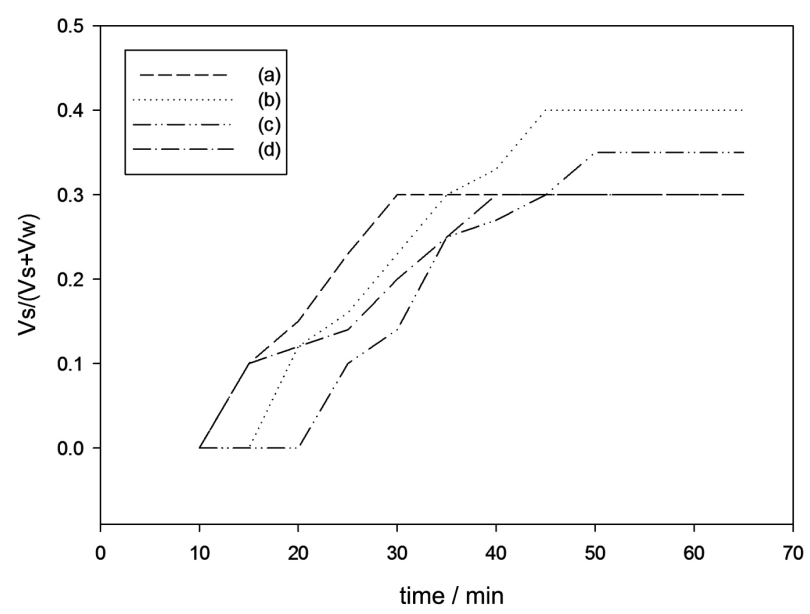

Figure 8. Comparison of phase change processes in terms of surfactant concentration on the surfactant-rich phase volume percentage for the four studied systems. (a) DC-193 nonanoic acid system; (b) DC-193 sodium sulfate system; (c) DC-193 lauric acid system; (d) Triton X-100 sulfate system.

\section{Interferences}

According to the previous experiments, potential interfering glucocorticoids in human urine samples have no obvious interferences. In addition, peak retention time is almost unchanged as compared with Standard whether in water or human urine. The results are shown in Table 3.

\section{Application analysis}

The analytical results obtained by the proposed method were compared with those obtained by the methods used
Table 3. The peak retention time of analyte in different matrices

\begin{tabular}{lccc}
\hline Analyte & $\begin{array}{c}\mathrm{PRT}^{\mathrm{a}} \text { of } \\
\text { standards / } \min \end{array}$ & $\begin{array}{c}\mathrm{PRT}^{\mathrm{a}} \text { in } \\
\text { water / } \mathrm{min}\end{array}$ & $\begin{array}{c}\mathrm{PRT}^{\mathrm{a}} \text { in human } \\
\text { urine / min }\end{array}$ \\
\hline BD & 2.868 & 2.881 & 2.882 \\
$\mathrm{HB}$ & 3.529 & 3.555 & 3.557 \\
$\mathrm{NPP}$ & 6.587 & 6.726 & 6.728 \\
\hline
\end{tabular}

${ }^{\text {aPeak retention time. }}$

in the literature for analyzing glucocorticoids in urine samples. Under the optimum conditions as described above, the results presented indicated that the proposed method provided similar or higher sensitivity. The LOD thus estimated was $1.29 \mathrm{ng} \mathrm{mL}^{-1}$ for $\mathrm{BD}, 2.67 \mathrm{ng} \mathrm{mL}^{-1}$ for $\mathrm{HB}, 3.33 \mathrm{ng} \mathrm{mL}^{-1}$ for NPP, respectively (Table 4).

The LC-MS/MS technique serves as an effective analytical tool for analyzing glucocorticoids, but it is expensive and could not be easily obtained from common analytical laboratory when it was compared with HPLC-UV. ${ }^{24}$ The recovery of glucocorticoids that was rapid and effective to attain $85 \%$ by CUS-CPE was similar or better than literature reported data (Table 5).

\section{Stability and accuracy}

The recoveries for the addition of different concentrations of glucocorticoids to samples are in the range of 85.1 to $88.5 \%$, and the results are shown in Tables 6 and 7. The background response in blank sample was subtracted. The stability of glucocorticoids was evaluated by determining a sample repeatedly at $0,6,12$ and $24 \mathrm{~h}$ with a represents means of per concentration level in each day (RSD) $<3 \%$ $(n=6)$, which shows that the derivatives of glucocorticoids had a good stability within $24 \mathrm{~h}$.

Table 4. Linearity range of calibration plot, LOD, LOQ and precision (\% RSD) of CUS-CPE method

\begin{tabular}{lcccccc}
\hline Analyte & $\begin{array}{c}\mathrm{RSD} / \% \\
(\mathrm{n}=6)\end{array}$ & $\mathrm{RE}^{\mathrm{a}}$ & $\mathrm{LR}^{\mathrm{b}} /\left(\mathrm{ng} \mathrm{mL} \mathrm{mL}^{-1}\right)$ & $\left.\mathrm{LOD} /(\mathrm{ng} \mathrm{mL})^{-1}\right)$ & $\mathrm{LOQ} /\left(\mathrm{ng} \mathrm{mL}^{-1}\right)$ & $\begin{array}{c}\text { Correlation } \\
\left.\mathrm{coefficient}^{2}\right)\end{array}$ \\
\hline BD & 2.1 & $\mathrm{Y}=55.201 \mathrm{x}-16.669$ & $1-350$ & 1.29 & 5.16 & 0.9996 \\
$\mathrm{HB}$ & 2.0 & $\mathrm{Y}=38.232 \mathrm{x}+30.650$ & $1-350$ & 2.67 & 11.68 & 0.9996 \\
NPP & 2.1 & $\mathrm{Y}=82.693 \mathrm{x}+5.197$ & $1-350$ & 3.33 & 14.32 & 0.9996 \\
\hline
\end{tabular}

Regression equation; 'linearity range.

Table 5. Comparison of the proposed method with literature reported data

\begin{tabular}{llcccc}
\hline Extraction method & Technique & $\mathrm{LR}^{\mathrm{a}} /\left(\mathrm{ng} \mathrm{mL} \mathrm{mL}^{-1}\right)$ & $\begin{array}{c}\mathrm{RSD} / \% \\
(\mathrm{n}=6)\end{array}$ & LOD / (ng $\left.\mathrm{mL}^{-1}\right)$ & References $^{1}$ \\
\hline- & UHPLC-MS/MS & $44-4400$ & 1.8 & 10 & 1 \\
- & HPLC & $2.55-40.8$ & 0.61 & 2.55 & 25 \\
LLE & LC-MS/MS & $2.0-200.0$ & - & 1.0 & 26 \\
CUS-CPE & present study (HPLC-UV) & $1-350$ & $<3$ & 1.29 & \\
\hline
\end{tabular}

${ }^{\mathrm{a}}$ Linearity range. 
Table 6. Intra-day precision and recoveries of glucocorticoids $(n=6)$

\begin{tabular}{lcccc}
\hline Compounds & $\begin{array}{c}\text { Spiked concentration / } \\
\left(\mathrm{ng} \mathrm{mL}^{-1}\right)\end{array}$ & $\begin{array}{c}\text { Measured concentration / } \\
\left(\mathrm{ng} \mathrm{mL}^{-1}\right)\end{array}$ & $\begin{array}{c}\text { RSD / \% } \\
(\mathrm{n}=6)\end{array}$ & Recovery / \% \\
\hline BD & 50 & 42.6 & 2.3 & 85.3 \\
& 150 & 129.3 & 2.0 & 86.2 \\
HB & 300 & 260.7 & 1.8 & 86.9 \\
& 50 & 42.8 & 1.5 & 85.7 \\
NPP & 150 & 128.7 & 2.1 & 85.8 \\
& 300 & 265.5 & 2.0 & 88.5 \\
& 50 & 42.9 & 2.1 & 85.8 \\
& 128.2 & 1.3 & 85.5 \\
\end{tabular}

Table 7. Inter-day precision and recoveries of glucocorticoids $(n=6)$

\begin{tabular}{|c|c|c|c|c|}
\hline Compounds & $\begin{array}{l}\text { Spiked concentration / } \\
\left(\mathrm{ng} \mathrm{mL}^{-1}\right)\end{array}$ & $\begin{array}{l}\text { Measured concentration / } \\
\left(\mathrm{ng} \mathrm{mL}^{-1}\right)\end{array}$ & $\begin{array}{c}\mathrm{RSD} / \% \\
(\mathrm{n}=6)\end{array}$ & Recovery / \% \\
\hline $\mathrm{BD}$ & $\begin{array}{c}50 \\
150 \\
300\end{array}$ & $\begin{array}{c}42.5 \\
129.3 \\
260.1\end{array}$ & $\begin{array}{l}2.5 \\
2.3 \\
1.9\end{array}$ & $\begin{array}{l}85.1 \\
86.2 \\
86.7\end{array}$ \\
\hline $\mathrm{HB}$ & $\begin{array}{c}50 \\
150 \\
300\end{array}$ & $\begin{array}{c}42.8 \\
128.5 \\
264.9\end{array}$ & $\begin{array}{l}1.7 \\
2.6 \\
2.3\end{array}$ & $\begin{array}{l}85.6 \\
85.7 \\
88.3\end{array}$ \\
\hline NPP & $\begin{array}{c}50 \\
150 \\
300\end{array}$ & $\begin{array}{c}42.8 \\
127.9 \\
261.6\end{array}$ & $\begin{array}{l}2.5 \\
1.6 \\
2.7\end{array}$ & $\begin{array}{l}85.6 \\
85.3 \\
87.2\end{array}$ \\
\hline
\end{tabular}

A total of $300 \mathrm{~mL}$ healthy volunteers diluted urine sample was divided into 60 portions of $5 \mathrm{~mL}$ each. All these portions were detected throughout 3 days, 18 portions per day. Then the intra-assay variation and the inter-assay variation of the method were determined, whose RSD\% were both below $3 \%$. The recovery was determined by measuring a blank urine sample and the same urine sample enriched with glucocorticosteroids at three concentration levels. Results were shown in Tables 6 and 7.

\section{Validation of the method}

To assess the practical applicability of the proposed method, the optimized extraction conditions were adopted to evaluate performance characteristics such as LOD and limit of quantification (LOQ). Linearity was investigated from 1-350 $\mathrm{ng} \mathrm{mL}^{-1}$ (each of the glucocorticoids at 1, 5, 25, 50, 100, 150 and $350 \mathrm{ng} \mathrm{mL}^{-1}$ ) by plotting the HPLC-UV peak areas of mixed standard solution against the concentrations in the spiked actual samples. The data were processed using Analyst software (Applied-Biosystems). For the quantification of the glucocorticoids in the actual samples, weighted least-squares regression analysis of the standard curves were used. The correlation coefficients were determined to be 0.9996 which are acceptable for trace analysis. Thus, a proportional relationship can be calculated between the amount of analytes extracted and the concentration of the samples. The LOQ was determined at $\mathrm{S} / \mathrm{N}=10$, which was 5.16, 11.68 and $14.32 \mathrm{ng} \mathrm{mL}^{-1}$ for $\mathrm{BD}$, HB and NPP, respectively (Table 4). The low LOQ value is sufficient to measure the concentration of glucocorticoids in urine samples.

\section{Conclusions}

CUS-CPE using DC-193 non-ionic surfactants has been proven to be an effective pre-concentration method that is specific and sensitive for the analysis of glucocorticoids and potentially for other hydrophobic compounds by HPLCUV. Several points are worth noting: (i) DC-193-nonanoic acid system had higher recovery, EF, good linearity and repeatability; (ii) the process of the CUS-CPE also reveals that the nonanoic acid acts as a cosurfactant that has influence on CP. The effect of the CP temperature may be related to hydrophilicity and space structure of organic acids and solubilization position: $;^{20}$ (iii) the phase separation and variation of the surfactants DC-193 mixtures with nonanoic acid also differs dramatically from the phase diagrams.

In addition, four systems (DC-193-nonanoic acid, DC-193-sodium sulfate, DC-193-lauric acid and the 
classic Triton X-100 sulfate system) has been compared containing recovery, $\mathrm{EF}$, the mechanism of the lower $\mathrm{CP}$ from the addition of organic acid. Hence, the method is a useful tool for official residue control analyses and is used as such in our laboratory.

\section{Acknowledgments}

This study was supported by the Tumor Hospital of Yunnan Province, Kunming 650106, China.

\section{References}

1. Wu, F. K.; Jiagen, L. V.; Talanta 2007, 72, 1811.

2. Cvoro, A.; Korac, G.; Cell Biol. Int. 2003, 27, 403.

3. Baynes, T. M.; Jimenez, A. L.; Craigmill, J. E.; Riviere, R.; Toxicol. Appl. Pharmacol. 1999, 29, 287.

4. Lurdes, I. B.; Filipe, D. P.; Freitas, A. P.; Rocha-Santos, A. C.; Talanta 2009, 80, 853.

5. Santos-Montes, A.; Gasco-Lopez, A. I.; Zquierdo-Hornillos, R. I.; J. Chromatogr., A 1994, 652, 83.

6. Chen, Q.; Zielinski, D.; Chen, J.; Koski, A.; Werst, D.; Nowak, S.; J. Pharm. Biomed. Anal. 2008, 48, 732.

7. Malone, E. M.; Elliott, C. T.; Regan, L.; Anal. Chim. Acta 2009, 637, 112

8. Beitollahi, H.; Karimi-Maleh, H.; Khabazzadeh, H.; Anal. Chem. 2008, 80, 9848.

9. Hamid, R.; Zare, N. N.; Sens. Actuators, B 2010, 143, 666.

10. McWhinney, B. C.; Ward, G.; Hickman, P. E.; Clin. Chem. (Washington, DC, U. S.) 1996, 42, 979.

11. Collado, M. S.; Robles, J. C.; Zan, M. D.; Camara, M. S.; Mantovani, V. E.; Goicoechea, H. C.; Int. J. Pharm. 2001, 229,
205.

12. Wasch, K. D.; Brabander, H. D.; Courtheyn, D.; Peteghem, C. V.; Analyst (Cambridge, United Kingdom) 1998, 123, 2415.

13. Shibasaki, H.; Furuta, T.; Kasuya, Y.; J. Chromatogr., B: Anal. Technol. Biomed. Life Sci. 1997, 692, 7.

14. Tlgye, D.; Virenderk, S.; Lorna, K.; J. Chromatogr., B: Anal. Technol. Biomed. Life Sci. 2010, 878, 1471.

15. Balaji, K.; Raghunadha Reddy, G. V.; Madhusudana Reddy, T.; Afr. J. Pharm. Pharmaco. 2008, 2, 157.

16. Yao, B. J.; Yang, L.; Sep. Sci. Technol. 2009, 44, 476.

17. Yao, B. J.; Yang, L.; Ind. Eng. Chem. Res. 2008, 47, 3949.

18. Yao, B. J.; Yang, L.; Qiong, H.; Akita, S.; Chin. J. Chem. Eng. 2007, 15, 468.

19. Su, X. J.; J. Anhui Agr. Sci. 2011, 239, 5814.

20. Shen, M.; Guo, R.; Liu, Z. M.; Chem. J. Chinese Univ. 1996, 10,1603.

21. Liang, R.; Wang, Z. L.; Xu, J. H.; Li, W.; Qi, H. S.; Sep. Purif. Technol. 2009, 66, 248.

22. Chen, M.; Xia, Q. H.; Liu, M. S.; Yang, Y. L.; J. Food Sci. 2011, $76,1$.

23. Baig Jameel, A.; Kazi Tasneem, G.; Shah Abdul, Q.; Anal. Chim. Acta 2009, 651, 57.

24. Wu, M.; Zheng, X. H.; Qi, S. L.; Phys. Test. Chem. Anal. 2010, $46,1282$.

25. Zhu, X. S.; Liao, J.; Huang, X. J.; China Pharm. 2009, $20,2463$.

26. Salem, I. I.; Alkhatib, M.; Najib, N.; J. Pharm. Biomed. Anal. 2011, 56, 983.

Submitted: August 23, 2012 Published online: December 7, 2012 